\title{
THE WAY COSEN BY MAHMUDKHOJA BEHBUDIY
}

\author{
Mustafaev Jafar Shomirzaevich \\ teacher of Samarkand Institute of Economics and Service \\ Phone: +99897394 4889, \\ Samarkand, Uzbekistan. \\ Usmonov Behruz Sharofiddin o'g'li \\ Samarkand Institute of Economics Samarkand, Uzbekistan.
}

Annotation. This article deals with the spread of the Jadid movement in Turkestan, Behbudi's role, participation and contribution to this movement. It also includes concepts on the national liberation movements, national and cultural development, education and upbringing, socio-political events in Uzbekistan in the late XIX and early XX centuries.

Keywords: jadidism, jadid, Mahmudhoja Behbudi, "Mirror of the world", reform, secular sciences, press, national interests, national liberation movement, literature, education.

After the Republic of Uzbekistan gained its independence, one of the most actual issues has been the restoration of the names of the representatives of the national liberation movement, the formation of a sense of respect to them, the awakening of a sense of patriotism in all our youth. Mahmudhoja Behbudi was a playwright, a sharp writer, a man of religious and secular knowledge, one of the leaders of the Jadid movement in Turkestan and also a great scholar of his time. Behbudi, who served as Mufti, had deep knoledge in Islam and Islamic jurisprudence. As an example of this, $\mathrm{H}$. Vamberi marvels saying that "such a free expression of ideas against the stereotypes of Islam, such a free analysis of ideas flowing with the light of the Qur'an and Sunnah, is an absolutely unique event in Islam"1

indicates that Jadid reforms started in the second half of the XIX century. It seems that J. Yuldashev and S. Khasanov directly describe Marjani and his followers (Mentor Fozil of Gijduvan, Muminkhoja Vobkandi, Mullah Khudoiber

Boysuni and others) as "Jadids of that time. ${ }^{2}$

Establishment of a new type school-education system, one of the main basic systems of Jadid ideas, also dates back to the end of the XIX century, which cannot be ignored. If Ismailbek Gaspirali's first "usul savtiya" school was established in 1884, which allowed children to learn the material in two years which took five years in the old schools, the first such educational institution in Turkestan was founded in 1898 in Kokand due to the efforts of the teacher Salohiddin Majidi. In the same year, this initiative was supported in practice in the village of Tuqliq, Yettisuv region and in the city of Prizhivalsk, then in Tashkent in 1899 by Mannon Qori, in Andijan by Shamsiddin domla. ${ }^{3}$

Professor N. Karimov believes that these arguments are not enough to explain the importance of Jadidism in Turkestan, and he mentions the date of 1900-1904 when he got familiarized with Jadids such as Abdulla Avloni, Hamza Hakimzoda, Sadriddin Aini, as well as the newspapers of other local intellectuals, such as "Time" (Orenburg), "Translator" (Bakhchasaray), "Habil ul -Matn" (India), "Chekhranoma" (Egypt) as the beginning of the movement. "The purpose of quoting these words of A. Avloni and Hamza, - says the author, - is to confirm that the Uzbek Jadids appeared under the influence of newspapers such as "Tarjumon" in the early twentieth century". ${ }^{4}$

Agreeing that the names of the eminent scholars in "... the above-mentioned newspapers opened the eyes of the younger generation, acquainted them with the fact that the twentieth century has entered as the century of social series, scientific and technological discoveries, and radically changed their worldview" ${ }^{\prime 5}$, we note that these publications also began to enter Turkestan not in the early twentieth century, but in the late nineteenth century. The following lines of the famous Jadid Haji Mu'in Shukrullo oglu from Samarkand testify to this, "This newspaper, - says the historian of the press, - has been coming to Samarkand since 1889. This newspaper was first read by Haji Abduqadir Memor from the local people (in 1889). A little later, the author reiterates, "The first of the press, which regularly came to Samarkand which was loved and read everywhere, was the "Shura" complex with the newspapers "Tarjumon" and "Vaqt". ${ }^{6}$

Thus, the idea of Jadidism in Turkestan appeared in the last quarter of the XIX century, even when we take into account the time when the representatives got acquainted with the progressive publications, in which the current issues of life were raised. Moreover, in the words of A. Avloni, "open-minded youth" like Zokirjon Kholmukhammad oglu Furkat

\footnotetext{
${ }^{1}$ Vamberi X • Awakening on the Path of Enlightenment. // «Tafakkur», 2000, issue 2, page 67.

${ }^{2}$ Yuldoshev J., Khasanov S. Fundamentals of modern pedagogy. - T., «Teacher», 1994, pages 25-26.

${ }^{3}$ Yuldoshev J., Khasanov S. Fundamentals of modern pedagogy. - T., «Teacher», 1994. p. 25; Al-Fargani. What were the Jadid schools like? // «Literature and art of Uzbekistan», 1997, July 18.

${ }^{4}$ Karimov N. The historical situation in the early twentieth century and the emergence of the Jadid movement./ "Jadidism: ...", page- 25

${ }^{5}$ The above source, p.26.

${ }^{6}$ Mu'in X - History of Samarkand press. // Editor of the newspaper "Zarafshon" May 5, 1923, issue 44, journalist N.Fayziev.
} 
(1858-1909), Sattorkhon Abdugafforov (1814-1901), Ishakhon Junaydulla oglu Ibrat (1862-1937) expressed their views in the newspaper "Turkistan region newspaper" even before the beginning of the XX century (July 1870 - February 1917). For instance, when Furkat lived in Margilan, he did not know Russian customs at all, however, when he came to Tashkent, he wrote poems such as "Gymnasium", "About Suvorov", "About a ball", and in newspapers he expressed his views as "... we need to know their pictures (customs), because there is trade and many other relevant activities between us, and we must consider the life of the Russian people for our own benefit". ${ }^{7}$ Sattorkhan worked as an assistant editor and translator in the newspaper from 1883 to $1889^{8}$. In this regard, it is worth noting that academician I. Muminov, Furkat and his contemporaries used the press, and even the governor-general's newspaper "Turkistan Region Newspaper" in the national interest. $^{9}$

We can see in the example of the national liberation uprisings of 1892 and 1898 that the slogan of the struggle for independence, that is, the main idea of the Jadid movement began to take root in the minds of the people at the end of the XIX century. The popular uprising of 1892 was sparked by the spread of plague in Tashkent during the summer months, when the governor-general and the city's leader (Muhammad Yakub) and governor (Putintsev) looked on to prevent it, ordering not to bury the dead in city cemeteries. According to some estimates, about 100 people died from the plague every day ${ }^{10}$. More than 10,000 people took part in the uprising, and the echo spread throughout the country. This uprising, though suppressed, left an indelible mark on the oppressed people as the national struggle and oppression against Russian government's colonial policy, and also influenced on the subsequent national liberation movements in the country. ${ }^{11}$

In the Andijan uprising of 1898, Dukchi Eshan, son of Muhammadali Khalfa Sabir proved that there was a growing need for unity among the people, scholars and the upper class in the struggle against the common enemy - tsarism", which led to the unity of all sections of the nation". ${ }^{12}$

On this basis, B. Kasimov says that Jadidism, one of the most important events of our recent socio-spiritual history, "... appeared in the 90s of the XIX century and lasted until the 30s of the new era". ${ }^{13}$ He also writes in his literature works that the Jadid movement "... begins from afar, from the invasion of Turkestan". In this way, we do not limit this period to 1865-1929. The literature of this period is truly new literature. It varies from form to content. It is a literature that awakened the nation and led to independence. This is its first and most important feature". ${ }^{14}$

However, it must be acknowledged that it takes some time for the ideas to become a large-scale practical action, that is, for the consistent implementation of new ideas in Jadid thought, and for the situation to mature. Indeed, "A certain idea first appears in the mind of any person. At the same time, it has a high social meaning and becomes a universal reality because it reflects the noble aspirations of society for development ". ${ }^{15}$ Similarly, the ideas of Jadidism, which had taken root in the nineteenth century, became a regular practical movement in the early twentieth century, and there can be no other basis for denying this. In this regard, it is true that Abu Mas'ud Mahmudhoja bin Qari Behbudhoja Khatib Samarkandi also appeared on the stage of history in the early twentieth century as a Jadid representative.

\section{Conclusion}

In conclusion, first of all, the owner of a sharp pen, as a man of high taste, was able to correctly assess the sociopolitical situation in the early twentieth century. This worldview will be the methodological basis for today's young professionals to choose the path of enlightenment, acquiring both religious and secular knowledge. His main idea was that upbringing should come from the family and education from educational institutions. Second, the influx of mass media, especially newspapers and magazines, into the territory of Turkestan has contributed to the comprehensive growth of the consciousness of the local population. As early as the nineteenth century, he emphasized the importance of investing in human capital in society, and reiterated in his writings that it could bring economic benefits to society. ${ }^{16}$ Third, the national liberation movement, the slogan of the struggle for independence, that is, the main idea of the Jadid movement, began to take a firm place in the minds of the people in the late nineteenth and early twentieth centuries. Fourth, the weighty works created by the sharp representatives of the field of literature served to enrich our socio-spiritual history

\footnotetext{
${ }^{7}$ The quote is taken from the article of the literary critic N.Abdul Hakim "The world is beautiful with knowledge ...". // «World Literature», 2001, August, page 123.

${ }^{8}$ Sattorxon. A Muslim from Shymkent wrote about his past. // Sahibqiron Yulduzi newspaper, March 24, 1998. (Translated and prepared for publication by Sh. Yusupov).

${ }^{9}$ Mo'minov I. From the history of socio-philosophical thinking of Uzbekistan. - T., UzFA Publishing House, I960, 168 pages.

${ }^{10}$ Ziyoev X • Struggle against Russian aggression and domination in Turkestan (early XVIII-early XX centuries). - T .. «Ma'rifat - Madadkor», 1998, p.368.

${ }^{11}$ Source above, pp. 382-383.

${ }^{12}$ The above source, p.387.

${ }^{13}$ Qosimov B. Jadidism. // «Uzbek language and literature», 1990, issue 4, page 15

${ }^{14}$ Kasimov B. Enlightenment of the awakened nation. // '"Literature and Art of Uzbekistan", 1994, March 25

${ }^{15}$ DREAM OF NATIONAL INDEPENDENCE: basic concepts and principles. - T., «Uzbekistan», 2000, p.

16 https: //scholar.googleusercontent.com/scholar? Q = cache: I0TZ3YYd5OIJ: scholar.google.com/\&hl=ru\&as_sdt $=0,5 \&$ as_ylo $=2021 \&$ scilib $=1$
} 


\section{References:}

1. Vamberi X • Awakening on the Path of Enlightenment. // «Tafakkur», 2000, issue 2, page 67.

2. Yuldoshev J., Khasanov S. Fundamentals of modern pedagogy. - T., «Teacher», 1994, pages 25-26.

3. Yuldoshev J., Khasanov S. Fundamentals of modern pedagogy.-T., «Teacher», 1994. p. 25; Al-Fargani. What were the Jadid schools like? // «Literature and art of Uzbekistan», 1997, July 18.

4. Karimov N. The historical situation in the early twentieth century and the emergence of the Jadid movement./ "Jadidism: ...", p.

5. The above source, p.26.

6. Mu'in X - History of Samarkand press. // Editor of the newspaper "Zarafshon" May 5, 1923, issue 44, journalist N.Fayziev.

7. The quote is taken from the article of the literary critic N.Abdul Hakim "The world is beautiful with knowledge ...". // «World Literature», 2001, August, page 123.

8. Sattorxon. A Muslim from Shymkent wrote about his past. // Sahibqiron Yulduzi newspaper, March 24, 1998. (Translated and prepared for publication by Sh. Yusupov).

9. Mo'minov I. From the history of socio-philosophical thinking of Uzbekistan. - T., UzFA Publishing House, I960, 168 pages.

10. Ziyoev X - Struggle against Russian aggression and domination in Turkestan (early XVIII-early XX centuries). - T .. «Ma'rifat - Madadkor», 1998, p.368.

11. Source above, pp. 382-383.

12. The above source, p.387.

13. Qosimov B. Jadidism. // «Uzbek language and literature», 1990, issue 4, page 15.

14. Kasimov B. Enlightenment of the awakened nation. // '"Literature and Art of Uzbekistan", 1994, March 25

15. DREAM OF NATIONAL INDEPENDENCE: basic concepts and principles. - T., «Uzbekistan», 2000, p.

16. https: //scholar.googleusercontent.com/scholar? Q $=$ cache: I0TZ3YYd5OIJ: scholar.google.com $/ \& h l=r u \& a s \_s d t=0,5 \& a s \_y l o=2021 \&$ scilib $=1$ 